\title{
HENDRIK DE MAN AND THE IDEOLOGY OF PLANISM*
}

\author{
Then came, with Christmas, \\ the Plan of Labour, thanks \\ to the powerful mind of Hendrik de Man.
}

On 26 December 1933 the front page of the socialist daily Vooruit (Forward) carries a lyrical description of the Christmas Congress of the Belgian Labour Party, already glorified by its old patron Emile Vandervelde as "the most wonderful socialist convention of the past 25 years". ${ }^{2}$ In a long speech on the first day of session "comrade Rik de Man" has elaborated the Plan of Labour. When he leaves the rostrum he is embraced by Vandervelde and flooded by the acclamations of the delegates. The next day de Man once more addresses the congress in a concluding speech, and dramatically beseeches it to close ranks for the oncoming struggle:

The great offensive against Reaction begins and everyone should now take up his responsibility. With us there can be no room for the dissatisfied [ . . ]. I ask you to vote in full conscience for the Plan of Labour. If you have doubts or lack confidence, vote against it. Today we declare a relentless war upon capitalism. Do not forget that the vote we will presently take carries the significance of an oath.

As soon as de Man steps down from the podium, Vooruit continues, "the hundreds of delegates rise and honour him with a magnificent ovation. It continues for minutes and all of a sudden hundreds of fists are stuck up in the air". The Plan having been adopted with more than half a million votes in favour, de Man is elected as vice-chairman of the Party; i.e. officially nominated as war chief of the projected action drive for the Plan. After a brief accolade by the deeply moved Vandervelde, the congress rises once again and sings the International. "The moment", Vooruit comments, "is very touching".

* This translation was prepared at the Center for European Studies, Harvard University, Fall 1986. I am indebted to its associates, staff, and students for some vivid interest shown in my subject and for offering an atmosphere of exciting intellectual companionship.

1 Désiré Bouchery at a planist meeting in Mechelen, introducing a speech by Hendrik de Man, as reported by De Volksgazet, 1-2 Dec. 1934.

2 Vooruit, 26 Dec. 1933. 
How was it possible that the Plan of Labour was sown into such fertile soil, and that its spiritual father could be welcomed by the party congress almost as a socialist messiah? And how could it happen that in the year of 1934 a propaganda drive of unprecedented dynamism could sweep the country under the slogan "Power to the Plan, the Plan into Power!" and that Hendrik de Man could traverse the land as an unintentional saviour, hailed and surrounded everywhere by hopeful socialist crowds? ${ }^{3}$ If we wish to understand this we need to make a thorough study of de Man's eventful personal life and intellectual development, of the reformulation of the socialist idea that undergirds planist ideology, and to the constricted position in which reformist parties such as the SPD and the BWP find themselves in the wake of the economic crisis of 1929 and the parallel rise of fascist movements and regimes all over Western Europe. The Christmas Congress of the BWP takes place in the middle of the whirlwind of crisis and unemployment which ravages Belgium, and under the long shadow of the power shift in January of the same year in neighbouring Germany. The Plan of Labour appears to speak magic in a situation where no one has an answer to this economic and political crisis; in a single master stroke, planism appears capable of remedying socialism's dragging ideological illness by providing a threefold alternative for Marxism, reformism, and national socialism. ${ }^{4}$

Just like the German SPD, which has been in power for an even longer period of time, the BWP is unprepared to face up to the crisis, and timidly clings to a traditional policy of deflation, austerity, and free trade. Resis-

${ }^{3}$ See the much-cited passus in de Man's memoirs which evidences his uneasiness about the 'personality cult' which accompanied planist agitation: "The more the people treated me as a kind of saviour, the heavier did this burden my conscience. I recall a typical winter night's scene when I arrived in a small Flemish industrial town, where I was expected to address a meeting. From the railway station to the meeting hall $I$ was surrounded and almost carried along by a crowd which shouted: There he is. There he is! Women kissed the lines of my overcoat, others held up their children for me to touch. Far from relishing in it I trembled, and when my travelling companion wondered why I was so dismayed by this impassioned reception, I answered him: But it is awful! I am no miracle doctor! And how difficult will it be not to disappoint these poor folk!'(Hendrik de Man. Persoon en ideeën, I, Standaard Wetenschappelijke Uitgeverij, Antwerpen/ Amsterdam, 1975, p. 287).

${ }^{4} \mathrm{Cf}$. for a fuller exposition of the economic and political background of planism (which is touched on very briefly here) Peter Dodge, Beyond Marxism. The Faith and Works of Hendrik de Man, Nijhoff, The Hague, 1966, ch. 6; Erik Hansen, "Depression Decade Crisis: Social Democracy and Planism in Belgium and the Netherlands 1929-39", Journal of Contemporary History, Vol. 16, 1981; and Michel Brélaz, Henri de Man. Une autre idée du socialisme, Genève, 1985, chs. 19-21. On the Dutch Plan see John Jansen van Galen et. al., Het moet, het kan! Op voor het Plan! Vijftig jaar Plan van de Arbeid, Bert Bakker, Amsterdam, 1985. Ch. 3 is an earlier Dutch version of the present article. 
tance against active conjunctural intervention is partly caused by the paralysing dilemma that social democracy sits both in the guise of physician and in the role of heir at the sickbed of capitalism - while the patient is in the long run moribund in any case. ${ }^{5}$ As the bankruptcy of reformist crisis politics becomes more evident, however, voices are raised in favour of more active state intervention. In 1932, for example, the German unions table a plan called Umbau der Wirtschaft, which seeks to finance employment through an energetic governmental credit policy. The British unions initiate a closely similar plan, which is partly fathered by the ideas of Keynes and G.D.H. Cole.

In Germany, the notion of Planwirtschaft has already emerged before that date, in response to the organization of a war economy of previously unprecedented scale. The major intellectual progenitor of the idea is the liberal technocrat Rathenau, although the concept also influences SPD top politicians such as Wissel and von Möllendorf. In France, Bertrand de Jouvenel publishes his l'Economie dirigée in 1928, although its impact remains limited to the 'rightist' tendance of the SFIO of which Marcel Déat is soon to become the leader. Interest in socialist planning has quickly faded during the years of economic prosperity which follow 1922, and is only revived when the new crisis of 1929 begins to eat into the fabric of society. Then also the idea takes root that it is perhaps due to the first five-year plan that the Soviet Union is able to steer clear of the economic danger zone. The SPD and the other socialist parties, however, doggedly persist in their opposition to planning and government intervention. As noted by Claeys, it is not the German unions or the SPD which will apply the main directives of Umbau der Wirtschaft, but eventually the NSDAP, which, although driven by quite different political objectives, will solve the unemployment question within a matter of years. ${ }^{6}$

\section{Hendrik de Man: The Biographical Dimension}

After having spent more than a decade in Germany, where he has watched and combated the rise of the NSDAP from close quarters, Hendrik de Man returns to Belgium in the spring of 1933,48 years of age. His motives for returning are twofold. On the one hand, he no longer feels capable of continuing his teaching at the University of Frankfurt under the Hitler

${ }^{5}$ M. Claeys-van Haegendoren, Hendrik de Man. Een biografie, Uitg. De Nederlandsche Boekhandel, Antwerpen/Utrecht, 1972; and by the same author, 25 Jaar Belgisch socialisme, Standaard, Antwerpen, 1967, pp. $286 \mathrm{ff}$.

${ }^{6}$ Claeys, Hendrik de Man, p. 166. 
regime (his book Die Sozialistische Idee, published in March 1933, ends up on Goebbels' bonfires as early as May); on the other he is enticed by Vandervelde's offer to head a new research bureau (or 'thought office' as it is termed in the Flemish edition of his memoirs) of the BWP, which is funded by the progressive factory-owner R. de Becker-Rémy. This 'planbureau', which aside from de Man employs four salaried officials, is soon encircled by an archipelago of specialized committees and can be considered the first modern-style, relatively independent scientific bureau sponsored by any West European socialist party. From this platform de Man launches the slogan of an "Economic Plan for Belgium" which is designed to combat crisis and reaction. Initial approval by the party and union leadership having been secured, a small committee is formed which swiftly reaches agreement on the first draft of the Plan of Labour, which will thereafter take the December Congress by storm.

It is not the first time that Hendrik de Man is recruited by Vandervelde from foreign parts in order to fill a key intellectual function in the party. More than two decades before, he had travelled nearly the same route with more or less the same destination, leaving England under the entreaties of the patron in order to become secretary of the Centrale voor Arbeidersopvoeding (Committee for Worker's Education) - which, by coincidence, also materialized thanks to a financial gift of a progressive 'class enemy'. At that date, however, de Man is still firmly in the grip of his revolutionary Marxist 'intoxication', which swayed him into signing up, at the age of 17 , with the Socialist Young Guards in his mother city of Antwerp, and which will continue to move him until the outbreak of World War I. Under pressure because of repeated conflicts with his parental bourgeois milieu, he departs in 1905 for Leipzig, at that time one of the capitals of West European Marxism. There he works as a journalist for the radical Leipziger Volkszeitung, following courses in economics, philosophy, psychology and history at the university, and completing these studies by writing a cum laude dissertation under the supervision of the historian Karl Bücher.

This peculiar parallelism between different career periods, which often appear to lead de Man twice along the same track, constitutes perhaps a unique feature of his life. No less extraordinary are the immediate interchanges between the emotional, intellectual, and political dimensions of his life, which often synchronize the conjuncture of the 'personal' and the 'political'. His prewar Marxist radicalism and his involvement with the anti-reformist wing of both the SPD and the BWP coincide with a period of bohemian existence which only partly comes to a close with his marriage to a Ghent millgirl in 1910. It is hardly an exaggeration to suggest that, with this gesture, the intellectual Marxist de Man also confirms his 'class treason' 
and consummates a 'churchly' marriage with the Proletariat.

Then comes in 1914 the terrible shock of the failure of the Socialist International. This emotional and political upheaval is likewise experienced by de Man in an immediate and bodily sense: driven along by inexpressible impulses, the convinced anti-militarist and internationalist registers as a war volunteer and spends long years in the trenches in defence of his fatherland. It is this uprooting experience which drives an irremovable wedge between life and doctrine and provokes the drawn-out 'farewell to the proletariat' which will culminate in The Psychology of Socialism of $1926 .{ }^{8}$ But as early as 1918 de Man already embraces many of the tenets of the revisionism and reformism of Bernstein and Jaurès. The year 1922, incidentally, witnesses the definitive breakdown of his first marriage, and de Man once again removes himself to Germany in order to build a new life with a former school companion who likewise issues from a respectable bourgeois family and also looks back upon the bitterness of a broken marriage; with her he enjoys for some years a happy family life in financially unencumbered conditions.

Without of course wishing to explain de Man's political development immediately from the events of his personal life, it is nonetheless evident that such pendulum swings between bohemianism and a life of comparative settlement and comfort are not without reflection upon the content and tone of his political doctrine. The Psychology of Socialism is a product of a different psychological mood to that which characterized de Man before the war, and in the book he attempts to give not only a psychoanalysis of Marxism, but simultaneously tries to disentangle his own previous motives. Adopting the major themes of theoretical revisionism, he also takes his 'sentimental' leave from revolutionary romanticism, and develops a keener eye for the advantages and inevitabilities of a step-by-step realization of the socialist final goal. His efforts to streamline revisionism into an ethically grounded, democratic, non-proletarian, and 'cultural' socialism and his approximations to the reformist method of action therefore coincide with a life period in which he not only personally attains a modicum of wealth and 'bourgeois' rootedness, but during which also the SPD, his political home, further accomodates to the bourgeois system - in a suddenly booming economic conjuncture which is especially tangible in Germany after 1922.

Then comes another caesura, and once again it is remarkable that the crisis in de Man's personal life chronologically matches the outbreak of a

${ }^{7}$ For further details, see Michel Brélaz, op. cit., pp. 157-61.

${ }^{8}$ For a broader perspective on the 'socialist front generation' see Dan S. White, "The Shaping of the Socialist Front Generation", unpubl. paper, 1982. 
new economic crisis, which hits Germany fast and hard, and coincides with a swiftly polarizing political and ideological climate in which social democracy increasingly stands empty-handed against the right- and left-wing extremisms of the NSDAP and the KPD. In 1929, also, de Man's second connubial attempt has run aground, leaving a grave disillusionment from which it will take him years to recover. He settles down once again in Frankfurt, lives in rented rooms on a meagre salary, without the security of a sheltered academic position; it seems as if the life of the bohemianintellectual which he had lived before the war must be lived all over again. De Man buries himself in intellectual work, having reached the stoical conclusion that he is not cut out for ordinary marriaged life. To some extent this personal débacle revives his youthful revolutionary mood and the soldierlike calling which deep down has never left him, although it has mellowed down in the meantime; now he rationalizes his misfortune through the conviction that the world will shortly find itself in the thick of a revolutionary struggle "in which it is imperative to carry the heaviest possible armament and the lightest possible intendance service". 9

\section{Revolutionary Revisionism}

Let me repeat: these facts of psychological sentiment and of cyclic alternation between marginal and established existence are by and large not sufficient to explain the rise (and decline) of something as elusive as a 'revolutionary will'. However, it appears to be an indispensable and relatively independent explanatory dimension which, if weighed separately, may pre-empt some of the more conspicuous intellectualistic prejudices of a traditional historiography of ideas, and hence do better justice to the stratified complexity of individual political motivation. Whereas in the incubation period of The Psychology of Socialism de Man emotionally approaches the axioms of reformism and gradualism, his 'planist' period from about 1933 in some sense features a comeback of the revolutionary sentiment - which however can no longer adapt to the Marxist doctrinal shell but is looking about for a new theoretical home. Hence planism must in some degree be rated as the product of an emotional change of colour of revisionist ideology: of a new combination between a Marx-revision on the level of theory and revolutionary fervour on the level of 'sentiment'.

This implies the need to introduce a distinction between revisionism and reformism; currents which initially develop in unison, but whose political

9 Claeys, p. 151. 
proximity is not a matter of self-evident necessity. Indeed, as early as the turn of the century, the socialist movement witnesses a parallel development of a 'liberal' or reformist revisionism (Bernstein, Bauer, Turati) and a 'revolutionary revisionism' (the term is coined by Robert Michels), which resemble one another in their common theoretical farewell to Marx and the proletariat, but divide sharply over the attitude to be taken towards bourgeois parliamentarianism and the 'established order' of which it is the political expression. While bourgeois revisionism does not swerve from the path of gradual reform by means of parliamentary politics, anti-bourgeois revisionism advocates the idea of a wholesale revolution under the guidance of an intellectual elite and based upon a 'popular' or völkische rather than a proletarian strategy. This is the lineage of the syndicalist revision of Marx which is initiated by Sorel, Michels, and Mussolini.

Now it seems inevitable that plan-socialism, through its novel combination of idea and sentiment, moves over in the direction of this 'revolutionary revisionism' and thus also approximates more closely to fascist ideology, which likewise weds an authentic revolutionary sentiment to theoretical notions which are partly derived from the Sorelian and Michelsian revision of Marx. It is remarkable that de Man is accused of a "barely disguised fascism" as early as the first presentation of the Plan in the autumn of $1933 ; ;^{10}$ an accusation which will be repeated many times in the year of agitprop which precedes his entry into the first Van Zeeland government in 1935, and which even today has not completely died away. In a recent scholarly work, the historian Zeev Sternhell has attempted to document these ideological resemblances between planism and fascism, departing from a similar thesis of the 'two revisionisms'; but the risk of his undertaking has been to play down the large differences which still remain between thinkers such as Michels and de Man, and to slide back into a principled anti-revisionism of Marxist inspiration which predicts that any reformulation of proletarian socialism will sooner or later, and of necessity, grow a hideous fascist face. ${ }^{11}$ The paradox of planist ideology, however, is that the revolutionary motive can no longer flow in traditional Marxist channels, and that a return to Marx is no longer a feasible ideological option; which implies guarded recognition of the need to learn from fascism, if not to acknowledge the partial correctness of fascist thought, if we

${ }^{10}$ See Blum's similar reaction at the SFIO Congress to the speeches by Marquet, Montagnon and Déat. On this, extensively, Emily Goodman, The Socialism of Marcel Déat, Stanford University Ph.D., 1973, pp. 182ff.

11 Zeev Sternhell, Ni droite ni gauche. L'idéologie fasciste en France, Seuil, Paris, 1983. For an extended critique see Dick Pels, "De zelfkant van het socialisme", Socialisme en Democratie, no 11, Nov. 1984. 
wish to explain it in any responsible manner and thus to devise an effective strategy of combat. ${ }^{12}$

In his memoirs, de Man does indeed not hesitate to argue that the victory of national socialism was "only the confirmation, and in large measure even the result of the decay of social democracy". He turns his attack against a "superficial anti-fascism" which not only bows excessively to the enemy's terms, and hence runs the risk of being defeated by an opponent with less political scruples than itself, but which also in practice identifies itself, through its stubbornly defensive attitude, with that which the enemy is out to attack, i.e. the established economic, social, and political order. As a result, social democracy counters the fascist critique of the political regime by rushing to the defence of the established order, although the latter is not really democratic but constitutes a "false capitalist democracy". Socialism wages a defensive war in order to preserve a crumbling earthwork instead of scaling an offensive in order to conquer new outposts. ${ }^{13}$ Hence de Man's predilection for a slogan which is not without spicy ambiguity: "In order to defeat the fascists, we should not practice anti-fascism but socialism". On one level, this can be understood to mean that fascism should not be combated blindly, but demands direct handling of its deep-seated causes in the structural crisis of capitalism. But on another level it is evident that plan-socialism undertakes to compete with fascism and, in doing so, finds itself adopting some of the latter's ideological themes and manners of style.

\section{The Planist Idea}

The densest definition which de Man offers of planism identifies it with "anti-crisis socialism", i.e. "a type of socialism which turns the continuous and theoretical struggle against capitalism into the topical and practical struggle against the capitalist crisis, or rather, against the crisis of capitalism". ${ }^{14}$ The heart of this formula is the fresh spirit of resistance against the crisis and the proclamation of the theoretical and practical "impossibility" of reformism. In the final chapter of The Socialist Idea de Man avows that he long believed in a renewal and reinforcement of the motive of reform without having to abandon the reformist method of action as such. In

${ }^{12}$ See Dick Pels, "De redelijkheid van het fascisme", Socialisme en Democratie, 2, Febr. 1982. Also Hendrik de Man, "Oude en nieuwe democratie", Leiding, in Persoon en ideeën, V, pp. 341-42.

${ }_{13}$ Herinneringen, p. 259; Hendrik de Man, Voor een Plan van Actie, De Wilde Roos, Brussel, n.d., pp. 22-23.

${ }^{14}$ Hendrik de Man, "Socialisme en Planisme" in Persoon en ideeën, IV, p. 304. 
present conditions, however, a change of mentality without corresponding change in the method of action itself has become impossible:

The existing social order is becoming less and less bearable every day, it is no longer susceptible to amelioration, but needs a complete overhaul. . . in present conditions nothing is more impractical than the attitude taken by self-styled practical men that one should go forward slowly and cautiously. In the revolutionary situation which presently obtains nothing can be less opportune than what until now constituted opportunism, nothing less possible than what the eldest, French school of reformism referred to as possibilisme $[\ldots] .^{15}$

Seen in this light, planism is nothing less than a 'third phase' in the history of socialism, of which the Marxist doctrine of catastrophe marks the first and the reformist politics of gradualism the second. In the first phase the recurrently erupting crises are seen as the Sternstunden of socialism, since they provide maximum opportunity for unleashing movements of revolt. In the second phase the crisis is rather conceived as a "waiting interlude" which only temporarily halts the inexorable progress of the socialist idea. The final goal is hence not renounced but relegated to "the domain of distant and dreamlike realizations". This divorce between end goal and practical demands of reform, and the defensive, irresolute policy which results therefrom condemns social democracy to impotence in a period of recession, so that national socialism is able to parade as the only movement which is capable of bringing the crisis to an end.

Planism, on the other hand, is an endeavour to turn from a defensive war of entrenchment to an offensive war of mobility, and an effort to bridge the gap between day-to-day agitation and future revolutionary consummation. Planism is revolutionary, de Man suggests, due to its revolutionary selection of goals, i.e. its orientation towards immediately implementable structural changes. This demands liquidation of the disparity between the minimum programme of daily practise and the maximum programme of principle, or otherwise expressed: all programmes must give way before the Plan, which fuses reformist demands and revolutionary motives together in mutual harmony:

The Plan as expression and symbol of the new phase of socialist agitation signifies that henceforth the revolution of the productive order must become an immediate demand. First on the agenda is the transformation of banking and credit into socialized common property, which is immediately followed by the socialization of large capitalist key industries which are already at the stage of monopolistic concentration; and in those countries where a class of big landowners survives, the expropriation of large landed property. These

${ }^{15}$ Hendrik de Man, De socialistische idee, in Persoon en ideeën, III, pp. 422, 429. 
are the changes which up till now comprised that part of the socialist programme of socialization which was considered a task not realizable in the immediate future. ${ }^{16}$

It is highly characteristic for de Man's philosophy that he attempts to justify such revolutionary politics of the will through an objective idealism which is a direct reversal of Marx' equally objective materialism, and which appears to fulfill broadly similar ideological functions. The crucial problem of a socialist theory of motivation, in his view, is how to restore the unity of means and ends (or of interests and ideas) which has been severed in the reformist creed; while it is simultaneously evident that the road which leads back towards Marx, who conceived the socialist goal as a compulsive reflection of the proletarian interest, is definitively blocked. De Man's solution, introduced as a "new dialectical turnabout in the relationship between means and ends", is a form of voluntarism in which ideas enjoy priority above interests, and interests in the realization of the socialist goal enjoy definitional priority above interested reactions "which are solely determined by the environment". Only ideal motives, which transcend the parameters of the established order, possess creative power; whereas motives of interest, de Man suggests, can never be creative.

In de Man's thinking the socialist idea and the socialist will which derives from it therefore possess an intrinsically revolutionary value. Accordingly, the history of the socialist movement may, in near-Hegelian fashion, be presented as "the history of a self-realizing idea", and its mobile principle be located in the continual clashes between the incarnations of this "eternally creative and revolutionary spirit" and the alienative reality of the capitalist environment. The socialist idea is intrinsically revolutionary because it channels demands that rest upon universally valid and humanistic sentiments of right and justice; although it should be noted that, as a movement grounded in ethical humanism, socialism is only the "executor of the will of bourgeois culture".

However, the idea itself is powerless if not supported by a movement of interest "which arises out of social necessity and through this necessity acquires the character of a mass movement". That movement, de Man thinks, is presently in evidence: the crisis proves that capitalism is riven by a growing internal tension and creates conditions which increasingly counter the forces that are striving towards socialism. The structural crisis deepens out towards a cultural crisis, shaking the confidence in the value hierarchy of capitalism in ever broader circles. ${ }^{17}$

\footnotetext{
16 Idem, p. 427.

17 Idem, pp. 418-21.
} 
It is questionable whether this scenario indeed exhibits a new unity between ideas and interests. The spirit is pictured as the creative principle, the sphere of interests only as the ripe earth in which it is sown. In comparison to Marx the order of priority appears to be radically reversed, since 'the idea' draws its revolutionary strength from its own private resources, and thus realizes itself in history practically under its own steam. More precisely it means that the motive power of class interest is replaced by "the concept and driving force of the general interest, conceived as the common interest of different classes which together make up the large majority $[\ldots] .{ }^{18}$

But in this 'spiritual' definition of socialism there is one particular interest which is silenced and defined out of existence: the interest of the 'spiritual estate' itself, which elevates its own revolutionary impulse into the 'disinterested' interest of the self-realizing idea. De Man's reversal of the order of constitution between idea and interest ultimately implies that the material self-interest and partisanship of the intellectuals is buried as effectively here as it is in the Marxist romanticizing of the proletariat. The revolutionary motive is taken to derive from the revolutionary essence of 'the idea' rather than vice versa; which saves it from suspicions of arbitrariness and subjectivity and anchors it securely in objective truth. Unnoticeably but unmistakably, the intellect thereby claims for itself a creative and leading role. This rehabilitation of "intellectuals' socialism" and its leadership claim already characterize de Man's revisionism in the Psychology period; in the final chapter of The Socialist Idea, where he exhorts a new generation of leaders and intellectuals to rally to the banner of the Plan, this elitism acquires a more emphatically revolutionary coloration. There may be no other passage in de Man's works where this high-minded missionary zeal expresses itself more clearly than at the end of his speech on "The Technicians and the Crisis" which is delivered at the zenith of Planist agitation in November 1934. Citing Marx's observation that human emancipation arises from the compact between "those who think" and "those who suffer", he prophecies:

That those who think because they suffer may be joined by those who suffer because they think. It is the intellectuals who, because their very function forces them to think according to the dictates of truth, come to know this social suffering, which simultaneously issues from reason and from conscience, like all thoughts which have directed humanity in whatever great things it has so far accomplished. ${ }^{19}$

${ }^{18}$ Hendrik de Man, "Socialisme en Planisme", p. 318.

19 Hendrik de Man, "De Technici en de Crisis", address pronounced in Liège, 10 Nov. 1934 , p. 33. 


\section{The "Front of Labour" against the "Wall of Money"}

A second complex of planist motives which is closely connected with this intellectual voluntarism arises from the sociological insight that socialism builds on quicksand if it continues to rely upon the Marxist scenario of the inescapable growth of the proletariat and the necessary unification of its class interests. First, the rationalization and automation of production result in a numerical stabilization and even diminution of the classical proletariat and a concomitant increase of the number of employees and unemployed; capitalism "depopulates the enterprises and populates the offices (and the dole counters)". The second premise is killed by the emergence of various horizontal and vertical lines of cleavage which carve up the allegedly homogeneous proletariat into opposing interest groups. Parallel processes of qualification and dequalification not only create a new stratum of qualified "machine operators, machine superintendents and machine builders", but also a "fifth estate" of totally dequalified workers who are chronically threatened by unemployment.

This new horizontal dividing line is accompanied by a second one, which separates the two proletarian strata from the 'proletarian' middle groups. Aside from the unexpected stabilization of the old middle class, a new middle class of employees, assistants and civil servants has emerged which since the turn of the century has conquered more and more sociological territory. In the present crisis these middle strata proletarianize as well, not through a relapse of individuals into the working class, but rather through collective descent along the social ladder. It reacts by cultivating an anticapitalist mood which is simultaneously anti-proletarian; it is this combination of ideological elements, de Man suggests, which presents

the psychological key to the riddle posed by the duality of the national fascism of the middle strata, which swings back and forth between hatred against capital and hatred against proletarian socialism - an inner contradiction which seeks to hide its face by transforming social resentment into national resentment. ${ }^{20}$

The working class is threatened by a similar translation of social resentment into nationalism, because it also subdivides along new vertical lines of cleavage; swept along by the evolution of capitalism towards economic nationalism and protectionism it is ever more inclined to identify with the interests of the national economies, which are themselves caught in a game of reciprocal closure.

The political upshot of these economic and sociological analyses is that a

De socialistische idee, p. 409. 
democratic-socialist majority strategy is only feasible if the front is broadened to include the middle classes, with the purpose of trying to 'bend back' their anti-capitalist vindictiveness in a socialist direction. What is no longer true for the proletariat, i.e. that its class interest tends to coincide with that of the great majority, is now true for the "Front of Labour", which is called upon to embrace all anti-capitalist classes. ${ }^{21}$ The breakthrough towards the middle class (and the non-socialist sections of the working class itself) demands a strategy of "popular unity" which requires the shake-up of traditional party relations and the transformation of the socialist labour party itself into a socialist people's party. In this respect, de Man suggests, the Plan is not a party programme but a programme to save the country which is only realizable with the support of "all elements of good will". ${ }^{22}$

That this new labour front is staked out very broadly is evident from de Man's analysis of the position and motives of what he refers to as "industrial intellectuals": the elite of the middle class which is made up of managers, engineers, and technicians in private enterprise. De Man here employs an optimistic version of the thesis of the 'managerial revolution', which premises an essential difference of economic function and psychological incentive between 'owners' and 'controllers'. Capitalist enterprise traditionally features two incentives or labour motives: the "financial" pursuit of profit and the "technical" pursuit of efficiency, which is simply "to produce more with less exertion". The motives of "credit" and "production", which originally marched in unison, have drifted apart in the present phase of capitalist evolution and increasingly assume a position of mutual contradiction.

De Man repeatedly harks back to Veblen's distinction between the "financier" and the "engineer" in order to clarify this motivational split, and leaves no doubt whatever about which of the two occupies a more elevated ethical plane. The development towards monopolization of credit and the domination of industrial capital by finance capital entails that the 'technical' motive (which he describes as "the historical justification of capitalism in its initial phase") is increasingly bottled up by the financial motive. This process of structural devaluation of technical labour functions and of concentration of control functions in the hands of financiers is accelerated during the crisis and speeds up these intellectuals' proletarianization. In the earlier-quoted speech on the technicians and the crisis, which is delivered to an enthusiastic membership of the General Union of

21 "Socialisme en Planisme", p. 319.

22 "De Technici en de Crisis", p. 32; also Hendrik de Man, "Klassenstrijd en Klassepartij", Leiding, in Persoon en ideeën, V, p. 330. 
Servants, Technicians, Shop Owners and Travelling Salesmen of Belgium, the contrast between the profit motive and the 'technical' motive is morally embellished in the following manner:

I am convinced that you are all stricken, not only physically but also morally, by the fact that you are obligated more and more to labour as subaltern and dependent salaried employees, under the command and to the advantage of people who are stirred by motives of a lower moral value than your own - the motives of the financiers to whom the labour of others is only a means of enrichment - whereas the true motive of the technician is work itself, labour as such. ${ }^{23}$

De Man does not hesitate to sharpen up this motivational contrast by pointing to the functionless, parasitical character of the financial caste and the anti-parasitism of the class of producers. Extrapolating his revisionist analyses from 1926, he observes that the actually productive functions of leadership, organisation, and initiative have since long been exercised by salaried intellectuals rather than by the capital-owners themselves. Presentday capitalism therefore not only witnesses a transition from competitional to monopoly or finance capitalism, but simultaneously represents an 'objective' degradation from productive towards usurer's capitalism. In this context de Man regularly resorts to the sociological invective of the "neofeudalism" of the financiers.

It is this "Wall of Money", defended by the celebrated " 137 families" of planist propaganda, which the Front of Labour has to scale. The creation and distribution of credit has become a crucial strategic switchboard in the modern capitalist mode of organization: whoever controls it simultaneously occupies the commanding heights of the national economy. The unfortunate fact that they are presently in the hands of financiers, who are driven by little else except the pursuit of private gain, has socially corrosive consequences in the present crises, which like all previous crises of capitalism is above all a crisis of overproduction and underconsumption. The withdrawal of capital from production inaugurates a vicious circle, since the destruction of production causes unemployment which will only aggravate the level of underconsumption and diminish effective demand even further; it all ends in the "crying paradox" that the primary needs of the populace remain untendered while both men and machines are forced to stand idle. The only way to break this vicious circle is to liberate credit from the regime of big finance and apply it to productive investments. This entails that control over credit must at once be made subservient to a planned economy which combats unemployment at root, primes the pump of production, and increases the level of effective demand.

23 "De Technici en de Crisis", pp. 15-16. 
This critical mustering of socialism's own troops, of those of its allies, and those of its enemies elicits a number of critical observations. First, de Man's picture of the interests and motivations of the intellectual vanguard of the working class matches those of the intellectual elite of the middle class to such an extent as to suggest the contours of a natural union between them. In both cases group motives are made to coincide with the general interest, or at least identified with that of the overwhelming majority of the populace. The 'truth interest' which is ascribed to the socialist intellectuals immediately squares with the disinterested 'technical' work motive of the engineers and managers. The humanistic, normative rationality which constitutes the basis for judgment of the former finds a natural complement in the technical and productivistic rationality of the latter. Although technicians are credited by de Man with a miscellany of laudable and less laudable motives, ${ }^{24}$ the technical incentive is nevertheless unmistakably romanticized, and stands together with the idyllic drive for justice of the socialist vanguard against the perfidious capitalist motive of gain.

Secondly, planist ideology reinforces a harsh agitatory dichotomy between the united front of those who "labour" and the "parasitic" power of money; which in its simplest form is merely a variant of the age-old theme of usury which also informed the fascist slogan of Brechung der Zinnsherrschaft. The rhetoric of such a polarization demands that the criteria for what may count as a 'productive' or 'functional' economic contribution are left entirely in the dark. That this is bound to lead to contradictions becomes evident where the financial caste is portrayed as an idle bunch of private proprietors, while it is simultaneously accused of concentrating all decisive control functions of modern organized capitalism in semi-collective economic institutions. A second difficulty would arise if the functions and incentives of "financiers" were not so easily divorceable from and potentially opposed to those of "technicians" as de Man insisted.

The foregoing can best be summarized by concluding that planism, due to its exclusive emphasis upon the control and socialization of financial capital, easily invites underestimation of the class-generating role of cultural capital. This applies not just to the enemy's or the allies' camp, but equally to the socialist movement itself. 'Cultural capital' indicates forms of legitimate knowledge or expertise which are monopolized by a social group and may supply the basis of an unequal distribution of power chances and income privileges. Both the disinterested "engineer's motive" and the disinterested "humanistic motive" of the planist vanguard may function as euphemisms or ideological embellishments of such interests, which may

${ }^{24}$ See Hendrik de Man, "Overwegingen over de geleide economie”, Persoon en ideeën, IV, p. 51. 
also be described as those of an embryonic 'New Class' of cultural capitalists. Planism, then, would have to be understood at least in part as the blueprint of a new class alliance between 'humanistic' and 'technical' intellectuals, and as a legitimation of the power claims of a new elite of 'knowledgeable organizers' versus those of the old.

\section{Socialization}

Inevitably, the redrawing of the socialist lines of battle undertaken by planism also entails a shift in the traditional image of socialization as the 'liquidation of private property'. Planism produces a differentiation in the doctrine of socialization which logically results from its fundamental notion of a directed but also mixed economy in which various property regimes coexist peacefully; and which also recognizes the structural fissure between 'ownership' and 'control' and the opportunity/necessity of socialist agitation within the borderlines of the national state. In the celebrated "Theses" which de Man proposes to the planist meeting in Pontigny in 1934 the latter two modifications are formulated thus:

a. national implementation is no longer to be subordinated to international implementation and takes priority, which means that the present stage of socialization can only be the national one;

b. the essence of socialization is less the transfer of ownership than the transfer of authority; or, more exactly, the issue of control takes precedence over that of possession, and modifications in the property regime are functions of modifications in the regime of authority which is established by the directed economy. ${ }^{25}$

The notion of a 'national' socialism bids a final farewell to the overstrung expectations of conventional internationalism; but it also evidences a willingness to take immediate action within the small margins of an open economy. Hence, it differs expressly from programmes of economic or political nationalism, and is not advanced as a matter of principle or final goal but as a point of departure which is dictated by hard facts. According to de Man, one must choose between two alternatives: "either one has to begin with "socialization in one country" as soon as one has the power, and only afterwards tackle the international problems, or one has to abandon socialization altogether [. . .]." ${ }^{26}$

\footnotetext{
25 "Socialisme en Planisme", p. 313. See also Peter Dodge, A Documentary Study of Hendrik de Man, Socialist Critic of Marxism, Princeton U.P., 1979, p. 303 (translation changed).

${ }^{26}$ De socialistische idee, p. 434; also "Socialisme en Planisme", p. 318. For a further elaboration of this traditional dilemma see Dick Pels, "Socialism Between State and Society", paper for the Symposium on "Socialist Theory at the End of the 20th Century", University of Groningen, The Netherlands, March 1987.
} 
The second modification in the concept of socialization, which shifts the analytic burden from ownership to control, is perhaps more significant but also traditionally generates a larger amount of confusion. In part this is caused by a purely verbal conflict - the functions and effects of which are however eminently political - which derives from the relative indefiniteness of the sociological inference that 'control' over the productive apparatus has now displaced 'ownership'. Orthodox socialists may advance the argument that the redirection of the socialization effort from property to power represents a sell-out of socialist principles, since the core structure of capitalism, private property, is left intact. Sternhell, who tends to regard the very notion of a 'mixed economy' as ideologically suspect, predictably holds that it is thereafter no longer a matter of "effecting changes in society, but of how to establish State authority over the economy [. . .]." ${ }^{27}$ Revisionists such as de Man, who underwrite the thesis of the "managerial revolution', will alternatively maintain that private property has slowly been eroded, and that the project to socialize dispositional control therefore tackles the core incidents of the former undivided bundle of ownership. If so, the shift from ownership to control follows the logic of the capitalist socialization of capital, which is increasingly subjected to institutional discipline so as to preclude direct and heritable possession by individual capitalists. That is why the Plan introduces the metaphor of "occupying the command posts of the economy" and proposes to monitor the rationalization of the banking system through a transferral of controlling stock which gives the state a voting majority in the future institutions of public credit. The terminological confusion therefore issues from the fact that the rivals employ different conceptions of property, one of which tends to include power titles whereas the other excludes them. This makes it more apposite to speak, not of a separation between control and ownership, but of one between control functions and income claims - such as those of 'functionless' shareholders. ${ }^{28}$

In addition, the Plan of Labour outlines a mixed economy in which the nationalized sector, where credit distribution and key industries such as raw

27 Sternhell, p. 211.

${ }^{28}$ However, in "Overwegingen over de geleide economie" de Man stipulates that one will never be able to establish a "directed capitalism" if one shies away from "radical modifications in the system of property" (p. 72). The verbal hassle over the priority of Power or Property also confuses the issue of the disposition over "cultural goods". Indeed, the specificity of cultural capital is that it represents something 'in between' power and property, or recombines elements of both into a new whole. The managers are perhaps less owners of physical or financial capital than 'private possessors' of cultural capital, and therefore come to resemble the political intelligentsia as far as their structural or 'class' position is concerned. For a perspective on this issue see Dick Pels, Property or Power? A Study in Intellectual Rivalry, University of Amsterdam, 1986. 
materials and energy supply are reorganized as public services, is flanked by a directed and an undirected market sector. In both of these private sectors the property system, though subordinate to the general directives of the Plan, is basically left untouched. The system as a whole therefore offers a flexible mixture of direct and indirect steering facilities distributed across a variety of public and market sectors. This, de Man suggests, will serve to utilize the spur of competition and thus the spirit of invention and productivity to the full, while the sovereign rationality of the plan will in turn curb its negative excesses. Aside from his principled acceptance of private property within the framework of the Plan, de Man also reasons that a free economic sector provides a counterweight against the threat of statism which lurks in every type of planned economy. Far from equating socialization and state ownership, de Man therefore refers to his own vision as a 'personalist-pluralist conception of socialization'.

In many of his expository comments, de Man cautiously referred to the Plan as representing only an "intermediate stage" between capitalism and socialism. Allegedly, the Plan of Labour was directed not against capitalism as such, but first and foremost against finance capitalism, and would leave the capitalism of free competition in specified sectors unharmed. This self-imposed restriction has often functioned to quieten down the fears of radical socialists, because the Plan would obviously only be a waystation on the road towards total socialization. On the other hand it frequently increased the radicals' lingering distrust of planism's 'petty bourgeois' nature. Indeed, one cannot lightly waive the suspicion that de Man does defend this mixed system as a matter of principle, and ultimately conceives of the integral liquidation of capitalism as an impossible and harmful dream. That is to say that his criticism of the banking regime and his demand for the nationalization of credit are less dictated by the opportunism of majority politics (finance capital being the common enemy of all "labourers" belonging to the working and middle class, while the middle class by itself is not prejudiced against property and competition) than inspired by a principled vision which relegates the integral socialization of property to the kingdom of the impracticable and the undesirable.

\section{Dilemmas of State and Democracy}

Roles should be reversed: henceforth the state must command the banks instead of being commanded by them! Hendrik de Man in Liège, 10 Nov 1934

Undoubtedly, one of the most resounding slogans in the propaganda for the Plan was the call for "a strong state which could tear down the wall of 
money". These few words are enough to present the essence of the modern dilemma of socialism and democracy; although planism also makes it more poignant through the novel emphasis of its positive doctrine of the state. The plea for a "strong state" implies a breach with socialism's traditional suspicion of political government - still given voice by Vandervelde in Le socialisme contre l'état - which identifies it primarily as the enemy's redoubt. In the planist view, the emphasis is no longer on 'smashing' the capitalist political machine but shifts towards the demolition of banking power through the agency of the state, which is deemed the only social organism strong enough to destroy the bulwark of finance in the interests of the social whole. The revolution 'from below' is therefore in part replaced by a revolution 'from above', carried through by a state which has become the power tool of planist rationality: "it is no longer through revolution that one can attain power: it is through power that one must attain the revolution".

This beneficial attitude towards the state as "mandatory of the common weal" and as potential headquarters of the campaign against the powers of finance should not simply be interpreted as an ideological crystal of social democracy's 'accomodation' to capitalist society. Although the reformist doctrine of the state already reluctantly moves in this direction, the planist exaltation of the 'strong' state effects a qualitative theoretical jump which is accentuated by a new 'elite theory' of democracy. This theory of political representation is already present in outline in The Psychology of Socialism, is further elaborated in Massen und Führer (1931), and receives a more authoritarian imprint in two subsequent article series in Leiding (Leadership) in 1939 and Le Travail in 1941. It bids a theoretical farewell to classical legitimations of bourgeois democracy which take their cue from the idea of popular sovereignty, and instead pleads the benefits of a functional difference between 'leaders' and 'led'. This difference, if applied to the organization of the state, is meant to fortify the right of initiative and power of decision of the executive vis-à-vis the legislature. To some extent the notion of a 'horizontal' division of powers is replaced by that of a vertical division: the executive power actually rules, the representative bodies monitor them.

However, in the political paragraph of the Plan of Labour and in de Man's speeches from the years 1933-34 these new political principles are still only vaguely profiled. Only subsequently, after his three-year service as a cabinet minister between March 1935 and March 1938, de Man realizes that the chapter about the reform of state and parliament constituted the weakest link in the chain of planist ideology, and goes on to credit much of the failure of the Plan to the fateful absence of serious attempts at political 
reform. The Plan drafts of 1933-34 still eclectically mix old and new principles. Proposals to strengthen the executive power are loosely combined with a project of corporative decentralization through "new organs" of economic administration; while the whole structure is still subordinated to a representative body chosen by popular vote which guards its sovereignty intact. The strong state, de Man writes, must be strong against the money powers, but not against parliament. In his brochure Corporatisme et socialisme from the same period it is likewise emphasized that the desired self-rule of the organized professions must in all events be mediated by a political state which is based upon general and equal suffrage. ${ }^{29}$

On closer inspection, however, two ideal-typical political blueprints appear to clash here, building up an internal tension which focuses upon the role of parliament. Despite his overt deference to its undiluted sovereignty, the 'modifications' and 'additions' proposed by de Man serve to progressjvely erode its traditional rights. Besides the extension of the executive's prerogatives, de Man also contemplates restricting the legislature to a single Chamber, "assisted" by heavyweight advisory committees, whose members are in part recruited outside parliament "by virtue of their recognized competence". In addition, new semi-public organs must be created with the purpose of administering the economic power of the state. "In order to avoid the dangers of etatism", the text of the Plan of Labour says,

Parliament will give to the agencies charged by law with the management of the economy those powers of implementation indispensable to rapidity of action and to the focusing of responsibility.

In the Pontigny Theses this project of corporatization is argued on similar grounds: in order to avoid bureaucratism and etatism

the new economic state must be differently organized from the former political state: autonomous corporative organization of firms nationalized or managed by the state, deparliamentarization of the procedures of control, necessary revision of the doctrine of the division of powers, etc. $[\ldots] .{ }^{30}$

Accordingly, the classical parliamentary model appears trapped between the upward pressure of the 'vertical' division of powers on the one hand and the simultaneous downward pressure of corporative decentralization on the other. Although planism is explicitly loyal to the constitutional means of majority formation within the established political system, and wishes to

${ }^{29}$ Hendrik de Man, Corporatisme en socialisme, Brussel, 1934, pp. 35-36.

30 "Plan van de Arbeid", in Persoon en ideeën, IV, p. 295; "Socialisme en Planisme", p. 314. Here cited from Peter Dodge, A Documentary Study, pp. 299, 303 (but translation changed). 
pose as liberal and democratic, these political blueprints maintain a strong undercurrent of criticism of parliamentary democracy and its system of party competition. De Man views this criticism as largely justified and on target, even if voiced by the fascist opponent; he will not tire from warning social democracy that, given the essential unity of socialism and democracy, there remains a world of difference between a "true, social, and proletarian democracy" and a "false, only parliamentary and formal bourgeois democracy". ${ }^{31}$ Both the new division of labour between the executive and legislative powers and the project of corporative decentralization are deemed steps on the road to such an 'authentic' social democracy.

It is altogether not surprising that de Man's critique of the parliamentary regime develops a sharper edge after his 'tropical years' in office in the two Van Zeeland governments and the Janson government, when he not only has to admit that the political breakthrough to the middle classes has failed but also that the most important objectives of the Plan of Labour have gone up in smoke. With greater or lesser justice the demise of the Plan is ascribed first of all to the stubborn resistance of the "Wall of Money" which still stands erect; but de Man is also profoundly disillusioned with the morals and effectiveness of parliamentary politics itself. ${ }^{32}$ In this period he resolves some of the contradictions in his previous political doctrine by establishing the absolute priority to be given to structural reform of the machinery of state, which should not exclude a change in the constitution itself. Meanwhile he moves over ever more distinctly towards the image of the 'strong state' and the notion of 'authoritarian democracy', so that not only the 'horizontal' separation of the powers of parliament but also the 'mixed state' of corporative decentralization progressively disappear into thin air. The leadership theory of democracy is more poignant here and the critique of parliamentary practice bites deeper; his political concern is less the installation of democratic counterweights against the state, but instead the fortification of governmental authority by 'de-parliamentarizing' the state and curbing the impact of party politics. In articles written during his collaborationist period, which interpret the victory of Nazi Germany as a Hegelian 'world verdict' pronounced upon rotten bourgeois democracy, the etatist spirit is entirely set free, so that ultimately the planist idea of 'authoritarian democracy' draws very near to the fascist theory of politics.

One ideological constant throughout all this variation is de Man's view that the state is no longer the "control council of the proprietors' interests". Not least through the political conquests of the socialist movement itself, it

${ }^{31}$ Hendrik de Man, Wende des Sozialismus (Ende des Reformismus), KPOD, Zürich, 1933, p. 12 (brochure form of article series in Hamburger Echo, Dec. 1932 - Jan. 1933).

${ }^{32}$ Cf., for example, Claeys, pp. 255-61. 
has been transformed into a neutral, supra-partisan instrument for the realization of the common weal. Recognition of the relative autonomy and intrinsic power of the state over external economic interests is therefore immediately processed into a utopian image in which the self-interest of the state as a sui generis institution is no longer taken into account. Since simultaneously everything is staked upon the fundamental antagonism between State and Big Bank (which often performs as a sociological embodiment of the old moral dualism between Good and Evil), attention is systematically averted from the risks of building a new, all-powerful Leviathan. In this sense there exists an elective affinity between de Man's "socialism of the intellectuals", which likewise magnifies partial into general interests, and his theory about the neutral state. Both exemplify a strategic blindness for the 'filthy underside' of the planist project, which in part voices the power claims of a new and technocratically minded elite. 'Disinterested' intellectuals and technicians, indeed, offer the personnel best fitted to man the 'disinterested' state.

\section{Conclusion}

It is perhaps manifest now that the recently recurring slogan "Back to the Plan" is not a well-paved alternative even for a social-democratic movement which has lost all theoretical inspiration. One plea in this direction is that made by the Belgian academic Freddy Verbruggen, who believes that, even though some aspects of the original Plan of Labour are time-bound and obsolete, its analysis and strategy "are essentially valid even today". Although the present economic crisis is certainly different from that of the thirties and the fascist threat less acute, the social lines of cleavage are still the same, and the attitude of the socialist party similarly hesitant and apathetic. The relationship between Political Power and Economic Power, Verbruggen holds, has not basically changed: the State continues to suffer the custodianship of Bank capital. The notion of the nationalization of credit is therefore as much alive as it was fifty years ago. ${ }^{33}$

However, it is questionable whether such a simple reprise of the Plan can fit our day and age. In the preceding pages, at least, I have attempted to demonstrate that the topical interest of planism cannot be judged without

${ }^{33}$ Freddy Verbruggen, "Terug naar het Plan van den Arbeid", Bulletin de l'Association pour l'étude de l'oeuvre d'Henri de Man, no 12, Dec. 1984, which is a special issue on planism. Cf. also the different statements by Piet Frantzen, Ernest Mandel, Marc Eyskens and Willy Claes in Hendrik de Man. Een portret 1885-1953, AMVC, Antwerpen, 1985. 
analysing its separate ideological elements; this permits neither an acrossthe-board rejection in the Sternhell style nor a full-scale renaissance after the example of Verbruggen. Moreover, I do not claim to offer an integral evaluation here, which would demand more intimate study of the political and economic conditions from which planist thinking arose and of its manifold offshoots in other European countries. Instead, I have thought it worthwhile to emphasize a limited number of ideological dilemmas and regularities whose exposition may facilitate such a future evaluation.

One of these recurrent themes is the definitely technocratic and intellectualistic quality of planism, which is often concealed behind false oppositions such as those between "Production and Credit", "general interest" and "private gain", or "state" and "big bank". Planism, in this respect, voluntarily succumbs to the eternal lure of all politics: which is to introduce one's opponent as the ultimate 'Other', who is absolutely excluded and exiled from the world which is considered one's own. The contrast between all those who "labour" by head or hand and the parasitic money powers, or that between the profit interest of a handful of monopolists and that of the "overwhelming majority" carries even less conviction in terms of an economic theory of exploitation as in terms of a political theory of interest articulation. Indeed, the financial caste was not as "devoid of function" as planist ideology predicted; nor was the advance guard of the "Front of Labour" as 'disinterested' as its self-image presented it. There is some reason to conclude that the good and the evil elite of planist ideology resembled each other in important respects, and that the struggle between the two would necessarily be in part fratricidal. This does not imply that the entire notion of "tearing down the wall of money", or that of a political and economic contrast between an 'intellectual' and a 'financial' elite has no meaning; it does however instil some relativity into the morale of combat. The political problem does not turn so much on how a 'do-nothing' class can be expropriated, but rather on how the socially indispensable functions of credit distribution and economic leadership can be withdrawn from the monopoly of specific self-recruiting and privileged groups.

The planist emphasis upon the control of credit and its axiom about the "unproductivity" of credit distribution results in a partial obfuscation of the function (and problem) of the organization of 'organized capitalism', which takes a like form both for the modern financial giants and for the modern state. As is known from a great deal of research, the large financial institutions continue to play a key role in the network of modern capitalism, not so much as cash registers or safety vaults but rather as switchboards of information and policy-making. Hence the issue of the socialization of credit has a much wider scope than that of the mere control of cash flows. In 
addition to this, the interfusion of political and economic sectors has progressed much further in our day than in de Man's time, so that the issue of the "antagonism" between political and economic powers and the issue whether one of them should enjoy "priority" above the other is increasingly beside the point.

One substantial weakness of planist socialism therefore is that it positions the functions of organization and leadership on the 'good' side of the labour/capital divide almost by definition, which turns state ownership of the private credit sector into a major advance towards socialist society. However, it is today less practicable than ever to embark upon socialization of the financial and economic sector without simultaneously undertaking the socialization of the state - as is demonstrated once again by the etatist derailment of planist thinking. The main issue, indeed, appears similar in importance and in its general dimensions for the public and private spheres: how to place sociologically and to face politically the new class of managers, politicians, and intellectuals which emerges at the point of intersection of the political and economic spheres, and whose personnel is supplied to a large extent by the socialist movement itself. Although Hendrik de Man was one of the first to spot the contours of this new class, his "intellectuals' socialism" also contributes to the problem instead of providing the master key to its solution. ${ }^{34}$

${ }^{34} \mathrm{Cf}$. for a more extended interpretation Dick Pels, "Hendrik de Man en de psychologie van het socialisme", Het Vijfde Jaarboek voor het Democratisch Socialisme, WBS/De Arbeiderspers, Amsterdam, 1984. A more general sociological background is provided by Alvin Gouldner, The Future of Intellectuals and the Rise of the New Class, Continuum, New York, 1979. 